\title{
Biopsy of Bone
}

National Cancer Institute

\section{Source}

National Cancer Institute. Biopsy of Bone. NCI Thesaurus. Code C51927.

Removal of bone tissue for microscopic examination. 